\title{
Conflicts of interest and efficient contracting in IPOs ${ }^{* \dagger}$
}

\author{
Alexander Ljungqvist \\ Stern School of Business \\ New York University \\ and $C E P R$
}

First draft: June 11, 2002

This draft: September 20, 2002

\footnotetext{
* I thank Michel Habib, Tim Jenkinson, Eli Ofek, Bill Wilhelm, and seminar participants at Columbia Business School, New York University, Notre Dame, Rutgers, and the 2002 Oxford Finance Symposium for helpful comments. All errors are my own.

${ }^{\dagger}$ Address for correspondence: Stern School of Business, New York University, Suite 9-190, 44 West Fourth Street, New York NY 10012-1126. Phone 212-998-0304. Fax 212-995-4233. e-mail aljungqv@ @stern.nyu.edu.
} 


\title{
Conflicts of interest and efficient contracting in IPOs
}

\begin{abstract}
We study the role of underwriter compensation in mitigating conflicts of interest between companies going public and their investment bankers. Making the bank's compensation more sensitive to the issuer's valuation should reduce agency conflicts and thus underpricing. Consistent with this prediction, we show that contracting on higher commissions in U.K. IPOs leads to significantly lower underpricing: a one percentage point increase in the commission rate reduces the initial return by 11 percentage points, after controlling for other influences on underpricing. Moreover, we present evidence consistent with issuers choosing commission rates optimally. Overall, our results indicate that issuers and banks contract efficiently in U.K. IPOs.
\end{abstract}

Key words: Initial public offerings; Underpricing; Intermediation; Integrated securities houses; Underwriting contracts.

JEL classification: G32, G24 


\section{Introduction}

Do investment banks maximize value to issuers when underwriting offerings of securities? Recent regulatory investigations in the U.S. appear to be motivated by the assumption that they do not. For instance, in January 2002, the Securities and Exchange Commission and NASD Regulation jointly fined CSFB \$100 million for "taking millions of dollars from customers in inflated commissions in exchange for allocations of "hot" Initial Public Offerings (IPOs)" between April 1999 and June 2000. ${ }^{1}$ Such allocations would have generated huge customer profits at a time when the average IPO was underpriced by 70 percent. Recent empirical research into IPO pricing also implicitly assumes a conflict of interest between investments banks and issuers leading to higher underpricing (Loughran and Ritter (2002a,b); Ljungqvist and Wilhelm (2003)). In their review article, Ritter and Welch (2002) view this as one of the most promising areas of IPO research.

In principle, issuers can mitigate this agency conflict in two ways: they can monitor the investment banks' selling effort and pricing behavior directly, or they can use contract design to realign the banks' incentives by making their compensation an increasing function of the offer price. Ljungqvist and Wilhelm (2003) provide evidence consistent with monitoring in the U.S., by showing that first-day returns are lower, the greater are the monitoring incentives of the issuing firms' CEOs. In this paper, we focus on the role of contract design.

In practice, banks typically buy the IPO shares from the issuer at the offer price less a spread. The spread is agreed well in advance of the offer price being fixed and typically is set as a fraction of the offer price (with seven percent being the dominant spread in the U.S.; see Chen and Ritter (2000)). Thus, the size of the spread can be thought of as the pay-for-performance sensitivity of the bank's compensation. All else equal, we would expect a higher spread to lead the bank to expend greater effort, resulting in offer prices being set higher, or equivalently, underpricing being reduced. 
This intuition is modeled formally by Baron (1982) in the context of a fixed-price offering and Biais, Bossaerts, and Rochet (2002) for bookbuilding efforts.

Testing these agency models with U.S. data is difficult for two reasons. First, as Chen and Ritter (2000) show, spreads cluster at seven percent so cross-sectional tests of the relation between spreads and underpricing have little power. ${ }^{2}$ Perhaps not surprisingly, therefore, Chen and Ritter fail to find a trade-off between underpricing and gross spreads in the U.S. Second, there is unobserved heterogeneity because researchers do not observe the bundle of services issuers expect to receive in return for the seven percent spread. These services include not only selling effort but also aftermarket price support and analyst coverage, among others. The part of the seven percent that goes toward inducing selling effort is thus not directly observable in the U.S.

IPO contracts in the U.K. are not subject to these shortcomings. First, there is no clustering. Banks' compensation takes the form of a linear, two-part function consisting of a flat fee and a percentage commission on shares sold that varies between zero and seven percent. (Clearly the flat fee has no effort incentive properties at the margin. Flat fees are rare if not unheard of in the U.S.) Second, IPO contracts in the U.K. lack the uniformity we see in the U.S. They explicitly outline the bundle of services issuers buy, and issuers' choices are very heterogeneous.

This heterogeneity allows us to estimate the cost drivers that make up the commission, and thus to isolate econometrically that part of the commission that goes toward inducing selling effort. Linking this to realized underpricing, we show that contracting on higher commissions leads to significantly lower underpricing: a one percentage point increase in the commission rate reduces the initial return by 11 percentage points, after controlling for other influences on underpricing. Moreover, we present evidence consistent with issuers choosing commission rates optimally. These results do not appear to be driven by endogeneity concerns or outliers. Overall, our results indicate that issuers and banks contract efficiently in U.K. IPOs. 
In investigating the role of underwriter compensation, we control for a feature of the U.K. institutional framework that is largely absent in the U.S. In the U.K. marketplace, investment banks' organizational structure is much less homogenized than in the U.S. Banks specializing in either corporate finance or institutional brokerage co-exist with the more familiar U.S.-style integrated securities houses (many of which are U.S.-owned). The integration of the corporate finance and brokerage functions can lead to conflicts of interest to the detriment of either issuers or investors, depending on whether the bank views future business with corporations or with investors as the more lucrative. Banks that specialize in corporate finance rather than brokerage business should not be subject to such conflicts of interest. In other words, when pricing an IPO they are more likely to look after issuers' interests, leading to lower underpricing. Consistent with this prediction, our results show that issuers that choose relatively more specialized corporate finance advisers experience much reduced underpricing.

Our empirical model has three components. Beginning with the last, we wish to test the comparative static prediction that higher commissions reduce initial returns. Commissions are endogenous and so we need to model them explicitly to mitigate the possibility of endogeneity bias in the initial return regression. Commissions reflect not only issuers' intended pay-for-performance incentives but also the bundle of IPO services they have negotiated with their banks. These services are presumably also chosen endogenously, so we first need to model issuers' demands for them to mitigate the possibility of selection bias in the commission equation.

The paper proceeds as follows. Section 2 details the sample and data sources. Section 3 describes U.K. IPO contracts and estimates the determinants of issuers' demands for the various IPO services. Section 4 models commissions. Section 5 analyzes the link between commissions and underpricing and provides various robustness tests. Section 6 concludes. 


\section{Sample and Data}

\subsection{Data and Sources}

Our dataset spans the period January 1991 to December 2001 and is an updated version of the dataset compiled by Ljungqvist and Wilhelm (2002) which ends in May 2000. The list of IPOs was obtained from the London Stock Exchange, Dealogic's Equityware, and Thomson Financial's SDC and covers companies listing in London irrespective of their country of origin. After excluding IPOs by investment trusts, companies previously listed elsewhere, and introductions (listings not accompanied by the sale of securities), there were 1,058 IPOs in the U.K. over the sample period. For 1,008 of these, we are able to obtain the IPO contracts from filings with the London Stock Exchange and the U.K. Listing Authority. From these contracts, we extract information regarding the commission rate and flat fee elements of the compensation function. From the prospectuses, we hand-collect data on company age, sales, debt, industry affiliation, and ownership structure at the time of the IPO, as well as offer prices and gross proceeds. First-day trading prices are from Datastream, with all initial returns in excess of 30 percent cross-checked using Reuters. We lack after-market prices for 10 IPOs. Cumulative inflation over the sample period is 36.9 percent using the Retail Price Inflation index (excluding mortgage interest), so we express all currency amounts in December 2001 purchasing power. To control for the effect of withdrawn IPOs, we identify 290 offers that were cancelled or postponed between 1991 and 2001 using filings with the London Stock Exchange and the U.K. Listing Authority and a Reuters news search.

\subsection{Descriptive Statistics}

Table 1 provides descriptive sample statistics for the overall period and by year. IPO volume fluctuates considerably, ranging from 16 IPOs in 1991 to 228 in 2000, with more than 100 new issues in 1994, 1996, 1997, and 2000. The average (median) company raised $£ 53.3$ million (£9.5 
million) in its IPO. This is lower than gross proceeds in the U.S. during the 1990s (Ljungqvist and Wilhelm (2003)). What is even more different is the time trend: while in the U.S., companies raised more and more money as the IPO market grew hotter towards the end of the decade, median gross proceeds declined substantially in the U.K.

Just under half of the companies listed on the junior market tier (the Unlisted Securities Market, USM, from 1991 to 1995, and the Alternative Investment Market, AIM, from June 1995), rather than on the Official List. As Table 1 shows, junior market listings account for a larger fraction of the sample in the second half of the period, following the opening of AIM.

Next, Table 1 describes certain firm characteristics that we will use to control for ex ante uncertainty about the issuer's valuation. At the time of its IPO, the average (median) company was 20.3 (eight) years old. Over the period, age at issue declined substantially, and at the peak of the hot market in 1999-2000, the median company went public three to five years after commencing operations. Again, this is roughly comparable to the U.S. during the 1990s (Ljungqvist and Wilhelm (2003)). Based on a reading of the business description section of the prospectus, internet-related firms account for 14 percent of the sample overall, and 31 to 44.8 percent in 1999 through 2000, mirroring developments in the U.S. The level of "indebtedness" at the time of the IPO (which listing rules define as secured and unsecured loans, bank overdrafts, leasing commitments, and loan guarantees) averages $£ 38.5$ million in real terms (median: $£ 1.8$ million). As James and Wier (1990) argue, the presence of credit relationships can reduce valuation uncertainty. To control for size effects we include revenue. In the last twelve month accounting period before the IPO, the average (median) company had sales of $£ 74.4$ million (£6.8 million).

The final two columns of Table 1 show the mean and standard deviation of first-day returns. Initial returns average 29.3 percent over the period, with notable spikes in 1999 and 2000 when the 
average IPO jumped in price by 80.8 percent and 65.4 percent on its first day of trading, respectively. These spikes also mirror conditions in the U.S. IPO market at the time.

\section{The Structure of U.K. IPO Contracts}

\subsection{Contracting Environment}

The London Stock Exchange requires IPO issuers to hire a "sponsor" (or, on AIM, a "nominated adviser") and a "nominated broker". The sponsor fulfills the same role as the lead manager's corporate finance department in a U.S. IPO, such as valuing the company and helping prepare the IPO prospectus. The broker places the stock with investors in much the same way as a lead manager's equity capital markets desk does in the U.S. Sponsor and broker need not be the same bank. In our sample, they are different in 39.6 percent of cases.

Conceptually, there are three types of sponsor in the U.K. marketplace: those (such as Baring Brothers or N.M. Rothschild \& Sons) that rarely or never act as brokers; integrated securities houses (such as Morgan Stanley or UBS Warburg) that usually broker the deals they sponsor; and brokers (such as Cazenove \& Co or HSBC James Capel) that only occasionally act as sponsor but whose specialty is to broker deals. These differences in specialization likely affect how well a sponsor's interests are aligned with those of the issuer. We will later propose a measure of the sponsor's independence of the interests of buy-side investors to distinguish between these cases.

Following the IPO, the sponsor and broker continue to work for the issuer and receive annual retainers in return. Importantly, a nominated broker would be expected to market the stock to institutional investors in the after-market, not least by publishing analyst research on an on-going basis. Thus, IPO issuers in the U.K. explicitly purchase analyst coverage.

The typical sequence of an IPO in the U.K. is as follows. About one month prior to listing, the company releases a "pathfinder" prospectus which resembles a "red herring" in the U.S., except that 
it need not disclose the offer price range. The pathfinder contains a draft contract between the issuer, the sponsor, and the broker, setting out the duties and responsibilities of the parties as well as

the banks' IPO compensation in the form of a flat fee and a commission rate. ${ }^{3,4}$ As in U.S. seasoned offers (Bhagat and Frost (1986)), contracts are negotiated rather than awarded through competitive sealed bid auctions. The final prospectus containing the offer price is released on "impact day", about 10 days prior to listing. At this point, the IPO contract becomes binding conditional on the Exchange approving the listing by a certain date, typically no later than three weeks after impact day. Following impact day, the broker endeavors to place the shares with investors.

\subsection{Bank Compensation}

The compensation the sponsor and broker receive for their IPO services follows one of three main schedules in the U.K.:

- The linear, two-part function consisting of a flat fee and a percentage commission on shares sold is the dominant form, and is used in 797 of the 1,008 contracts in the sample. This includes two special cases: 156 contracts where the banks received no flat fee, resembling U.S. practice, and 79 contracts where the banks received only a flat fee and no commission.

- Some contracts combine a flat fee with different commission rates for different parts of the offer. In offers open to the public prior to January 1996, banks were typically paid a higher commission on shares placed with retail investors than on shares placed with institutions (89 cases). And in some rare cases, insiders pay a commission rate on the shares they sell in the IPO that is higher (eight cases) or lower (18 cases) than the rate the company pays on newly issued stock. In either case, we compute and report the weighted average commission rate (since that is the lead manager's expected marginal compensation) and so treat the compensation schedule as a linear, two-part function. 
- The commission rate can also be a step function of the number of shares placed or of proceeds raised. For instance, banks might be paid three percent for the first 10 million raised, rising to four percent for the next five million. Such convex incentives are present in 31 contracts, including 13 cases where issuers offer the banks "performance bonuses" of between $1 / 2$ and one percent of gross proceeds, payable after the IPO at the sole discretion of the board. We have no information regarding the actual payment of the bonuses. The reverse, though rare, is possible too: lead managers may be paid a lower rate on additional shares sold. Such concave incentives are present in 15 contracts. For the purpose of our empirical tests, we compute average commission rates though our results are robust to using the (highest) marginal rate.

Table 2 provides details of IPO compensation in the U.K. We know the commission rate for 958 of the 1,008 contracts and the size of the flat fee for 795 . Commission rates average 2.01 percent over the period (median: 1.75 percent), with a pronounced positive drift from 1.41 percent in 1991 to 2.71 percent in 2001. The range (not shown) is zero to seven percent. The most frequent commission rate is three per cent (18.3 percent of cases), followed by $3 / 4$ percent (13.2 percent of cases) and two percent (8.4 percent of cases).

In December 2001 purchasing power the flat fee element averages $£ 139,060$ (median: $£ 88,434$ ). It exhibits a fair degree of variation but no clear trend over time. Together, the commission and flat fee (where disclosed) amount to 4.35 percent of gross proceeds for the average company (median: 3.78 percent), considerably less than the typical seven percent spread paid by U.S. companies (Chen and Ritter (2000)). Over time, there is a clear increasing trend, with both average and median total spreads nearly doubling between 1991 and 2001. If there are economies of scale in IPO costs, this trend is likely related to the decrease in gross proceeds over the period shown in Table 1.

With regard to bank compensation, IPOs in the U.K. cost only about two-thirds as much as IPOs in the U.S. (4.35 vs. seven percent). Part of the difference may be due to the British practice of 
keeping the sponsor and broker under contract after the IPO, which might promote the banks' willingness to spread some of their costs over time. In the U.S., by contrast, there is only an expectation that the lead bank will get future business (for a job well done).

In the average (median) IPO, the investment bank receives 43.4 (43.0) percent of its total realized compensation from the flat fee element and the remainder from commissions. (The expected proportions would have depended on the expected offer price and offer size at the time of contracting.) With the exception of 2001, which saw a shift towards flat fees, these proportions remained relatively stable over the period.

\subsection{IPO Services}

In addition to the distribution of their stock, what services do issuers purchase from the investment banks? We focus on five discretionary services that issuers may demand and that may increase the cost of their IPOs: underwriting cover, price support, marketing to investors in the U.S., retail participation, and post-IPO analyst coverage provided by the broker.

- As in U.S. firm-commitment offers, underwriting cover guarantees that the issuer will receive the net proceeds regardless of the broker's success in placing the stock. Unlike in the U.S., where deals are typically priced just hours before final allocations take place, U.K. banks tend to bear underwriting risk for several days following impact day. ${ }^{5}$ It is common for underwriters to lay off part of this risk by pre-placing shares with investors, who receive a commitment fee out of the underwriter's commission.

- Like in the U.S., banks managing an IPO in the U.K. are allowed to engage in activities that stabilize prices in the first month of trading. Unlike in the U.S., however, they can only do so if they have previously alerted investors to the possibility of price stabilization via an explicit 
statement in the IPO prospectus. ${ }^{6,7}$ This is not a boilerplate statement, suggesting that issuers decide whether or not to allow for price support on a case-by-case basis.

- Marketing in the U.S. requires either registration under the 1933 Securities Act or exemption under Rule 144A for sale to "qualified institutional buyers" only. In either case, the IPO prospectus includes a prominent disclaimer. Ljungqvist, Jenkinson, and Wilhelm (2003) show that marketing IPOs in the U.S., though more costly, leads to significant price improvement in a sample of new issues from 65 countries, particularly in less developed markets, perhaps because the involvement of U.S. investors improves competition among investors.

- Until January 1996, issues exceeding certain proceeds thresholds were required to offer shares to retail investors. Since January 1996, issuers can freely choose between a "placing" targeted solely at institutional or extremely wealthy investors, and offers that are open to retail investors (see Ljungqvist and Wilhelm (2002), Appendix C for further details). ${ }^{8}$

- As mentioned earlier, the bank brokering the IPO will usually provide analyst research coverage of the company after the IPO. The perceived quality of the research and the reputation of the broker's analysts are likely to affect institutional demand and liquidity.

To measure the reputation of the broker's analysts, we use the annual Extel Survey of Investment Analysts (now owned by Thomson Financial). The survey provides institutional investors' views on brokerage houses based on votes cast for individual analysts, weighted by the investors' funds under management. For instance, in 2001, UBS Warburg's analysts received 11.88 percent of all weighted votes cast, making it the highest ranked London broker. Our variable "analyst ranking" is defined as the percent of weighted votes the IPO issuer's broker received in the Extel survey published in the year the IPO takes place. For instance, "analyst ranking” equals 11.88 for all IPOs brokered by UBS Warburg in 2001. If a broker is not ranked in the Extel survey, it is given a score of zero. In the case of IPOs with multiple brokers, we compute the simple average of each broker's weighted votes. 
Table 3 shows that 67 percent of sample offerings were underwritten, 8.5 percent flagged the possibility of price support, 10.3 percent were marketed to U.S. investors, and 24.1 percent were open to retail investors. The average analyst ranking is 2.25 percent, which to put into perspective is a little higher than the 2.1 percent that earned Credit Lyonnais the number 10 rank in 1995. 62.7 percent of IPOs, accounting for 11.1 percent of money raised, used an unranked broker.

Underwriting cover was particularly popular in 1992-1994 when around 90 percent of issues were underwritten. Price support was particularly popular in 1991, 1999, and 2000, when more than 10 percent of issuers contracted to receive price support. Marketing to U.S. investors became more widespread towards the end of the period. Retail participation, on the other hand, declined over time as regulations requiring retail participation were first relaxed (in December 1993 and January 1995) and then abolished (in January 1996). Note, however, that around one in six issuers voluntarily chose to market their offerings to retail investors in 1996 through 2001. In the later years, more issuers use unranked brokers, but these are typically the smaller offerings.

\subsection{Issuer Demands for IPO Services}

With the exception of the underwriting decision, which has been analyzed in the literature on the choice between firm-commitment and best-efforts offers in the U.S. (see, for instance, Welch (1991)), issuers' demands for IPO services have not previously been modeled. Thus the empirical models reported in this section are exploratory. Their purpose is to allow us to control for the possibility that endogeneity in choosing IPO services biases our estimation of the relation between commissions and initial returns.

We conjecture that issuers' demands are a function of conditions in the stock market in general and the IPO market in particular, as well as offer and firm characteristics. We estimate probit models of the probability that an issue is underwritten, flags the possibility of price support, is 
marketed to U.S. investors, or is open to retail investors. To aid the economic interpretation of the results, columns (1) through (4) of Table 4 show the change in the probability for an infinitesimal change in each independent, continuous variable and, by default, the discrete change in the probability for dummy variables, rather than the probit coefficients. The regression of analyst ranking shown in column (5) is estimated using least-squares. White heteroskedasticity-consistent standard errors are shown in italics.

Looking across the five columns, the most consistent determinant of issuers' demands for the various services is offer size. The greater are $\log$ proceeds, the more likely are U.K. IPOs to be underwritten, to allow for price stabilization, to be marketed to U.S. investors, and to involve retail investors (after allowing for compulsory retail participation using dummies for the years 1991 through 1995). Firms raising larger amounts also hire brokers with higher-ranked analysts. The $t$ statistics are all in excess of seven. Thus, there are two main types of offering in the U.K. market: smaller IPOs that are placed with domestic institutions by brokers who provide no after-market price support and little if any research coverage; and larger issues that may include one or more of the additional IPO services in the table.

We might have expected that underwriting is more popular when the stock market is performing poorly (as measured by the return on the FT-SE All Share Index, excluding investments trusts, over the 180 calendar days before the pricing date), the market is more volatile (as measured by the standard deviation of daily index returns over the same period), and the IPO market is less "hot" (as measured by the average initial return and number of companies going public in the prior 180 days). ${ }^{9}$ The coefficients on these variables have the right signs but are imprecisely estimated. We do find, however, a significant relation $(p=0.046)$ between the demand for underwriting and the IPO withdrawal rate (which we define as the number of IPOs that are cancelled divided by the sum of completed and cancelled IPOs in the 12 months to pricing). The relation is negative, suggesting 
perhaps that banks are reluctant to underwrite securities at times when many IPOs are withdrawn. Finally, IPOs are more likely to be underwritten, the older the company $(p=0.095)$, if the issuer's business is not internet-related $(p=0.027)$, and if its CEO sells stock in the IPO $(p=0.026)$. The pseudo $R^{2}$ of 27.4 percent indicates the model has good overall explanatory power.

The demand for price support is unrelated to market returns but increases in market volatility ( $p$ $<0.001)$ and the number of recent IPOs $(p=0.009)$. It is lower for larger companies as measured by $\log$ sales $(p<0.001)$ and marginally higher for more indebted issuers $(p=0.071)$. U.S. marketing is more likely in more volatile markets $(p=0.037)$, among younger companies $(p=0.043)$, and the more equity the CEO owns before the IPO $(p=0.071)$. Controlling for time variation and size dependence in regulations mandating retail participation in the early years, companies are more likely to open their offers to retail investors the more indebted they are $(p=0.025)$ and when the CEO does not sell stock in the IPO $(p<0.001)$. The pseudo $R^{2}$ for these three models range from 30 percent to 59 percent. Finally, companies hire brokers with higher-ranked analysts, the fewer companies have recently gone public $(p=0.09)$, the larger they are in terms of log sales $(p=0.036)$, the greater their indebtedness $(p=0.045)$, if their business is internet-related $(p=0.066)$, and the less equity the CEO owns before the IPO $(p=0.018)$. The adjusted $R^{2}$ of 37.1 percent again indicates good fit.

\section{Commissions and Pay-for-performance Sensitivities}

\subsection{Estimation and Empirical Model}

To estimate the pay-for-performance sensitivity of the investment bank's compensation contract, we first need to estimate the contribution to the commission rate of the five services analyzed in the previous section. We hence regress commission rates on dummy variables for issues that are underwritten, have flagged the possibility of price support, are marketed in the U.S., or are 
open to retail investors, as well as on the analyst ranking variable. The coefficient estimates are measures of the marginal increase in commissions that is due to each service. ${ }^{10}$

Issuers presumably choose their bundles of services endogenously rather than randomly, so OLS coefficients are likely to be biased. To estimate consistent coefficients for the four binary variables, we use Heckman's (1979) two-step treatment effects model. In the first step, we generate inverse Mills' ratios from the four probit models in Table 4. In the second step, we include these alongside the binary variables in a least-squares regression with commission rates as the dependent variable. ${ }^{11}$ Non-zero coefficients estimated for the inverse Mills' ratios would indicate self-selection bias.

Broker ranking, on the other hand, is treated as exogenous. Using the model reported in column (5) of Table 4 as the auxiliary regression (with a dummy for VC backed companies added for identification), a Durbin-Wu-Hausman test (Davidson and MacKinnon (1993) pp. 237f) finds no evidence that broker ranking is endogenous with respect to the commission rate $(p=0.307)$. Thus, instrumenting broker ranking in the commission regression would only reduce the efficiency of the estimates.

We also control for other possible determinants of commissions. ${ }^{12} \mathrm{~A}$ bank that specializes in corporate finance work rather than institutional brokerage may have a relative cost disadvantage, and so charge higher fees, compared to an integrated securities house or a bank specializing in brokering deals. To measure the degree of specialization - or equivalently, the sponsor's independence of the interests of buy-side investors - we compute, for each of the 107 sponsors in the sample, the ratio of the number of deals the bank has sponsored over the sample period to the sum of the number of deals it has sponsored and the number of deals it has brokered. ${ }^{13,14}$ This ratio varies between zero and one. It equals one for a sponsor that never brokers IPOs, $1 / 2$ for an integrated securities house that brokers all the deals it sponsors, and less than $1 / 2$ for a broker that only occasionally acts as a sponsor. The median sample company uses an integrated securities 
house (independence measure of 0.49 ), while 23.4 percent of sample companies use a sponsor that never brokers IPOs. We interact our independence measure with a dummy equaling one if the sponsor also brokers the deal to control for fee differences when issuers hire two separate banks.

Marketing an IPO presumably requires greater effort in bearish or volatile markets or when many IPOs are being withdrawn. Periods of high initial returns may prompt issuers to offer higher commissions so as to reduce underpricing in their own offering. Similarly, when IPO volume is particularly high, the bank's opportunity cost of effort may increase (Altinkilic and Hansen (2000)) also prompting issuers to offer higher commissions. Thus, we include the market conditions variables from Table 4.

In the U.S., there is ample evidence of economies of scale in IPO spreads (see for instance Ritter (1987), Dunbar (2000), or James (1992)), with smaller issues paying higher spreads. ${ }^{15}$ Whether this will be the case for commissions in the U.K., however, is not clear: after all, issuers could cover the banks' fixed cost of managing an IPO via the flat fee. Nevertheless, we include log proceeds to allow for the possibility of economies of scale in commission rates.

Uncertainty about the issuer's value should increase the effort required in marketing the deal, so we include log age, log sales, log debt, and the internet dummy variable as uncertainty proxies. ${ }^{16}$

Finally, we allow for the possibility of substitution between contracting and monitoring in mitigation of the agency conflict between issuer and bank. Monitoring intensity is unobservable, but Ljungqvist and Wilhelm (2003) argue that the CEO will expend less effort monitoring on behalf of other shareholders when his stake in the outcome is smaller. His stake in the outcome is, in turn, related to the fraction of the equity he owns before the IPO and to whether he sells stock in the IPO (since Habib and Ljungqvist (2001) show that owners are more tolerant of underpricing the fewer shares they sell at the time of the IPO, because the benefit of costly monitoring then is smaller). For this, we hand-collect ownership and selling data from the prospectuses. The average (median) CEO 
in our sample owns 29 (20.5) percent of equity outstanding just before the IPO. CEOs sell stock in 35.3 percent of sample IPOs.

\subsection{Results}

Table 5 presents the coefficient estimates alongside White heteroskedasticity-consistent standard errors. Overall, the regression has good fit, given the adjusted $R^{2}$ of 37.6 percent. Commission rates are not significantly related to whether an offer is open to retail participation. Underwriting cover increases commission rates by 112 basis points on average $(p=0.023)$, and the negative and significant coefficient estimated for the inverse Mills' ratio indicates that self-selection would have caused OLS to estimate a downward-biased coefficient. Price stabilization increases commission rates by 176 basis points on average $(p=0.009)$, with no evidence of self-selection bias. Marketing to U.S. investors adds 206 basis points to the commission $(p=0.005)$, after correcting for self-selection. Taken together, these estimates confirm Altinkilic and Hansen's (2000) conjecture that bank compensation increases at the margin in the cost of services provided.

Analyst ranking does not have a significant effect on commissions. However, this does not rule that brokers with higher-ranked analysts charge issuers more via the annual post-IPO retainer.

Consistent with a cost disadvantage, relatively more independent sponsors charge higher commissions $(p=0.011)$. This effect does not depend on whether they also broker the deal $(p=$ 0.554 for the interaction term). In the next section, we will investigate whether hiring a more independent sponsor leads to an offsetting benefit, in the form of reduced underpricing.

Market conditions behave as predicted. Issuers pay higher commissions when index returns have been lower $(p=0.12)$ and in more volatile markets $(p<0.033)$. Volatility has the larger impact: a one standard deviation increase in daily volatility (equivalent to 0.26 percent) during the 180 days pre-pricing increases commissions by 12 basis points, whereas a one standard deviation 
fall in the level of market returns (equivalent to 7.94 percent) increases commissions by only seven basis points. Conditions in the IPO market also affect commissions. A one standard deviation increase in the level of underpricing during the 180 days pre-pricing (equivalent to 51.9 percent) increases commissions by 14 basis point $(p=0.027)$. This is consistent with issuers offering higher commissions in hot markets so as to reduce underpricing in their own offering. They also pay higher commissions, the more firms have gone public in the prior 180 days $(p=0.076)$ and the more firms have recently withdrawn their IPOs $(p=0.009)$, with one standard deviation increases in these variables increasing commissions by 12 and nine basis points, respectively.

Commissions decrease in log proceeds $(p=0.033)$ suggesting the presence of economies of scale. Altinkilic and Hansen (2000) advocate the use of a different functional form to allow for a Ushaped relation between underwriter compensation and issue size, using inverse proceeds and proceeds over pre-money market capitalization instead of log proceeds. However, including these variables does not alter our conclusion. ${ }^{17}$

Commissions increase in valuation uncertainty given the negative coefficient estimated for log sales $(p<0.001)$, though somewhat surprisingly we find a positive coefficient for log age $(p=$ $0.04)$.

Finally, we find strong evidence of substitution between contracting and monitoring. Issuers pay 22.3 basis points lower commissions when the CEO sells stock in the IPO and so has a personal interest in monitoring the banks' pricing and selling effort $(p=0.023)$.

If we take regression model (6) in Table 5 as the average pricing schedule, holding market conditions and firm/offer characteristics constant, we can impute each issuer's chosen pay-forperformance sensitivity as the difference between the actual commission agreed and the commission predicted by model (6). This "excess" commission rate will be positive (negative) when issuers pay more (less) than their bundle of services, market conditions, and characteristics 
require on average. In this view, higher effort incentives correspond to paying a commission rate in excess of that predicted by model (6).

\section{Commissions, Selling Effort, and Underpricing}

Do issuers design compensation contracts that induce investment banks to expend greater selling effort? If so, we expect excess commissions to have a negative effect on underpricing after controlling for other determinants of initial returns.

\subsection{An Empirical Model of Underpricing}

Most theories of IPO underpricing, including Baron's (1982) and Biais, Bossaerts, and Rochet's (2002) agency models, predict that initial returns are higher, the greater is the ex ante uncertainty about an issuer's value. We attempt to control for this using log age (as in Loughran and Ritter (2002b) and Ljungqvist and Wilhelm (2003)), log debt (as in James and Wier (1991) and Habib and Ljungqvist (2001)), and the internet dummy (as in Loughran and Ritter and Ljungqvist and Wilhelm). We do not include log proceeds or log sales as risk proxies, as neither is significantly related to initial returns in our data. This lack of correlation makes log proceeds and log sales good candidates for instruments. In particular, as shown in the previous section, they correlate significantly with commissions, ensuring that predicted and excess commissions from the first-stage regression in Table 5 can be properly instrumented for inclusion in the underpricing regression.

As discussed earlier, Ljungqvist and Wilhelm (2003) argue that underpricing will be higher, the less of a stake the CEO has in expending monitoring effort to reduce it, so we expect an inverse relation between initial returns and CEOs' equity stakes just before the IPO. Habib and Ljungqvist (2001) argue that insiders are more tolerant of underpricing, the fewer shares they sell at the time of the IPO, so we expect a negative relation between initial returns and a dummy equaling one when 
the CEO sells stock in the IPO - especially in view of the substitution effect between CEO selling and commission rates documented in the previous section.

There is controversy over whether conditions in the stock market impact initial returns. Loughran and Ritter (2002a) find that initial returns increase in prior market returns in the U.S., suggesting that underwriters fail to fully incorporate public information in the offer price, while Lowry and Schwert (2002) find no significant effect. In our model, we include the 180-day prepricing index return and daily return volatility.

Conditions in the IPO market are likely to impact initial returns, so we include the pre-pricing average level of underpricing, the number of deals completed in the previous 180 days, and the withdrawal rate. Lowry and Schwert (2002) show that initial returns exhibit relatively high persistence leading to extended periods of high underpricing. Benveniste and Spindt (1989) argue that investment banks can reduce underpricing by “bundling” deals (see Sherman's (2000) Proposition 2 for an elaboration of this point). A higher deal flow affords the banks the opportunity to cut off informed investors from future lucrative deals as punishment for misrepresenting their private information during bookbuilding. Higher deal flow should therefore lead to a lower marginal cost of acquiring information, i.e. less money being left on the table in the form of underpricing. Busaba, Benveniste, and Guo (2001) argue that underpricing is lower when the threat to withdraw an offering is greater, as this threat reduces informed investors' expected profit from understating their private information.

We allow for the possibility that the reputation of the firm's broker, as measured by the ranking of its analysts, reduces underpricing. Carter and Manaster (1990) argue that a higher-ranked underwriter can certify the quality of the issuing firm, leading investors to demand a smaller IPO discount. Alternatively, a higher-ranked broker may have access to a higher quality network of 
investors and so may be able to extract more information during bookbuilding. We initially treat the analyst ranking variable as exogenous, though we will later instrument it using 2SLS.

We saw in the previous section that relatively more independent sponsors charge higher commissions. We now investigate whether there is an offsetting benefit in the form of reduced underpricing. The U.K. distinction between sponsors and brokers allows issuers to hire a bank to advise them in their pricing negotiations with the broker, whose interests may be to leave more money on the table to benefit buy-side investors. The more specialized or independent the sponsor, in the sense of relying more on corporate finance work than on brokerage business, the harder a bargain it may drive with the broker. This effect should be stronger when a relatively more independent sponsor brokers the deal itself, as this removes a layer of agency.

Controlling for these factors, we expect excess commissions to be negatively related to initial returns. This is the central test of efficient contracting in IPOs.

Our empirical model also includes predicted commissions, which are orthogonal to excess commission by construction. They reflect the bundle of services issuers purchase which may, in turn, affect underpricing. For instance, knowledge that the bank stands ready to support prices in the after-market may lead uninformed investors to demand a lower initial return to compensate them for the winner's curse modeled by Rock (1996).

In sum, our empirical model of initial returns is of the following form:

$$
\text { initial returns }=f\left(\begin{array}{l}
\text { valuation uncertainty, } \\
\text { monitoring incentives, } \\
\text { conditions in the stock market, } \\
\text { conditions in the IPO market, } \\
\text { analyst ranking, } \\
\text { sponsor independence, } \\
\text { pay - for - performance incentives }
\end{array}\right)+\varepsilon
$$




\subsection{Results}

Table 6, model (7) presents the results of estimating the model outlined above using least squares. The overall fit of the model is good, in view of the adjusted $R^{2}$ of 10.9 percent. As conjectured, firms subject to lower valuation uncertainty experience less underpricing: initial returns decrease in log age $(p<0.001)$ and $\log$ debt $(p=0.002)$, while internet companies are significantly more underpriced $(p=0.01)$. Monitoring incentives behave as predicted: initial returns are lower, the greater the CEO's equity stake $(p=0.169)$ and when the CEO sells stock in the IPO $(p=0.013)$, though the former is imprecisely estimated in this specification. These results mirror the findings of Ljungqvist and Wilhelm (2003) for the U.S. Unlike Loughran and Ritter (2002a), we find no evidence that offer prices fail to incorporate recent market returns (or volatility). Conditions in the IPO market, on the other hand, do influence initial returns: a one percent increase in average underpricing in the 180 days before an issuer's pricing day leads to a 0.24 percent increase in the issuer's own initial return $(p=0.049)$, while initial returns decrease in IPO volume $(p=0.005)$, consistent with bundling. A one percent increase in the rate of IPO withdrawals reduces initial returns by 1.2 percent $(p=0.057)$, consistent with the argument in Busaba, Benveniste, and Guo (2001).

As conjectured, underpricing decreases in the reputation of the issuer's broker $(p=0.022)$ : a one standard deviation increase in the broker's analyst ranking (from a mean score of 2.3 to 6.6) reduces initial returns by four percentage points (from 27.9 percent to 23.9 percent), holding all other covariates at their sample means. Initial returns are also lower, the more independent the sponsor $(p$ $=0.033)$, particularly so if the sponsor brokers the deal itself $(p=0.03)$. A one standard deviation increase in our sponsor independence measure (from 0.622 to 0.878 ) reduces initial returns by 7.4 percentage points if the sponsor doesn't broker the IPO and by 13.9 percentage points if it does. This is likely to more than offset the higher level of commissions independent sponsors charge. 
Finally, predicted commissions correlate negatively with initial returns $(p=0.105)$, suggesting that more expensive bundles of IPO services reduce initial returns somewhat.

Controlling for these effects, we find that excess commissions are significantly and inversely related to initial returns $(p=0.038)$ : a one percentage point increase in excess commissions (a little under one standard deviation) reduces initial returns by 11.1 percentage points, from 27.9 percent to 16.8 percent. This provides strong evidence for the view that issuers can overcome agency problems by offering banks higher commission rates, and the magnitude of the effect indicates that providing banks with stronger pay-for-performance incentives has a large effect at the margin.

The magnitude of the effect deserves comment. Given the linear specification of model (7), the implied cost-benefit trade-off depends inversely on the level of underpricing. ${ }^{18}$ This suggests that the coefficient estimated for excess commissions is more reasonable for companies in the tail of the distribution, rather than the average firm. In Section 5.3.3, we will estimate a log specification which removes the scale dependence.

\subsection{Robustness}

\subsubsection{Endogeneity Considerations}

Model (7) accounts for the endogeneity of commissions but not of analyst ranking or sponsor independence. To test for the exogeneity of analyst ranking, we perform a Durbin-Wu-Hausman (DWH) test using the model for analyst ranking reported in column (5) of Table 4 as the auxiliary regression. The DWH test statistic is $F_{1,928}=5.64$ with $p=0.018$, so we reject the null that analyst ranking is exogenous with respect to initial returns. To test for the exogeneity of sponsor independence, we use as instruments a set of industry dummy variables which aggregate four-digit SIC codes into the 48 industry groupings studied by Fama and French (1997). The industry dummies are jointly significant at the five percent level in the auxiliary regression but not in the 
underpricing regression, and a robust Sargan test cannot reject the validity of the instrument set $(p=$ 0.974). The DWH test statistic is $F_{1,917}=1.41$ with $p=0.235$, so we cannot reject the null that sponsor independence is exogenous with respect to initial returns.

To generate consistent estimates of the effect of analyst ranking, we estimate a 2SLS version of model (7). As instruments, we use log proceeds and a dummy equal to one if the issuer is VCbacked, both of which correlate positively with analyst ranking but not with initial returns. (This is the same instrument set as in Ljungqvist and Wilhelm's (2003) model of U.S. IPOs.) A robust Sargan test of the implied overidentification restriction fails to reject the validity of these instruments $(p=0.428)$.

The results are reported as model (8). Consistent with the presence of endogeneity bias in (7), we find that the coefficient estimated for analyst ranking increases almost eightfold in absolute magnitude, making the effect much more economically significant. Excess commissions, on the other hand, continue to be inversely related to initial returns $(p=0.036)$ and the magnitude of the coefficient is virtually identical in models (7) and (8).

\subsubsection{Partial Adjustment}

Models (7) and (8) do not control for the partial adjustment phenomenon identified by Hanley (1993) and so may suffer from omitted variable bias. Hanley shows that initial returns are higher, the more the lead manager has revised the offer price upwards relative to the midpoint of the indicative price range filed prior to bookbuilding. This supports Benveniste and Spindt's (1989) prediction that underpricing will be greater for deals drawing strong interest from institutional investors during the bookbuilding effort. 
However, controlling for partial adjustment in the U.K. is complicated by the fact that it is unusual for issuers to file indicative price ranges (although potential investors are privately given valuation indications; see Ljungqvist and Wilhelm (2002) for further details).

We have indicative price ranges for 273 of the 1,008 sample firms. 113 are priced below the midpoint of the range, 23 are priced at the midpoint, and 137 are priced above the midpoint. In model (9), we include a variable that equals the price revision (offer price / midpoint - 1) when available, and zero otherwise. This is clearly a noisy measure of price revisions. The coefficient estimate is positive and less than one, consistent with Hanley's finding, and marginally significant $(p=0.062)$. Its inclusion does not, however, materially change the coefficients estimated for the other regressors.

\subsubsection{Omitted Variable Biases}

Other than partial adjustment, our model of initial returns controls for all the main economic determinants suggested by prior theory and empirical evidence. Omitted variable bias could still arise to the extent that our chosen proxies for such determinants fail to adequately capture the economic effects that need to be controlled. Perhaps the most important economic effect that needs to be controlled is firm-level valuation uncertainty. In unreported regressions, we have experimented with alternative proxies, such as book value of assets, asset tangibility, asset mix (current versus fixed), and pre-IPO cash flow profiles (levels and whether the issuer was cash flowpositive or not). None of these add anything at the margin.

\subsubsection{Outliers}

Initial return distributions are typically right-skewed. Regression results may, therefore, be sensitive to the presence of positive outliers. We address this concern in three ways. First, we estimate models (7) through (9) using an inter-quartile regression (a regression of the difference 
between the first and third quartile) rather than least squares (not shown). We continue to find a significant negative relation between initial returns and excess commissions ( $p=0.02$ or better).

Second, we estimate least-squares regressions of models (7) through (9) where the initial return is trimmed at either the first and $99^{\text {th }}$ percentile, or the fifth and $95^{\text {th }}$ percentile (not shown). In either case, we still find a negative and significant relation between initial returns and excess commissions. In the model (8) specification, for instance, a one percentage point increase in excess commissions reduces initial returns by seven percentage points $(p=0.002)$ and 1.8 percentage points $(p=0.015)$, respectively.

Finally, we replace the dependent variable in models (7) through (9) with the log of one plus the initial return. This removes the scale dependence of the implied cost-benefit trade-off between higher commissions and reduced underpricing. ${ }^{19}$ The results are shown in column (10) of Table 6. Our results are qualitatively unchanged, though the overall fit of the model improves. We continue to find that paying greater excess commissions reduces underpricing $(p=0.008)$. Not surprisingly, the magnitude of the effect is smaller: a one percentage point increase in excess commissions reduces $\log$ underpricing from 0.163 to 0.135 , holding all other covariates at their sample means. Unlike the linear specifications in models (7) through (10), the log specification thus suggests a reasonable magnitude for the cost-benefit trade-off for the average company.

\subsection{Optimality}

In light of our evidence that initial returns are negatively related to excess commissions in the cross-section, did issuers choose their commission rates optimally? The answer depends on the relation between the benefit of reducing underpricing further and the cost of paying the bank a higher commission. The benefit of reducing underpricing, in turn, depends on the size of the offer: the fewer shares are sold, the less the issuer's wealth is affected by a given degree of percentage 
underpricing (Barry (1989)). Habib and Ljungqvist (2001) formalize this argument and show that the appropriate objective function is to minimize not underpricing but "wealth losses" (the weighted average loss on shares sold and on shares retained, bearing in mind the diluting effect of issuing new shares at a discount to their true value).

If issuers did minimize wealth losses by inducing the constrained optimal level of bank effort, the partial derivative of wealth losses with respect to excess commissions should be zero. The coefficient on excess commissions in a regression of wealth losses on the other control variables in Table 6 is an estimate of this partial derivative. Demsetz and Lehn (1985) first proposed such an optimality test in the context of executive ownership, and Habib and Ljungqvist (2001) apply it to IPO issuers' choice of promotional expenses in the U.S.

Using the model (8) specification but with wealth losses (normalized by shares outstanding) as the dependent variable, we find that wealth losses are invariant to excess commissions $(p=0.398$, results not shown). The coefficient estimate of -0.014 indicates that a one percentage point increase in excess commissions would reduce wealth losses per share outstanding by only a little over one penny on average. The same result obtains if we measure excess commissions in pound sterling: increasing the excess commission paid to the sponsor and broker by $£ 1$ on the margin would reduce an issuer's wealth losses by only four pennies on average ( $p=0.759$, results not shown). This is consistent with issuers having chosen commission rates optimally.

\section{Conclusion}

Using IPO contracts from the U.K., this paper has provided evidence of efficient contracting between issuers and banks. Specifically, we have shown that when issuers pay banks abnormally high commissions, initial returns are substantially reduced. While this implies the existence of an 
agency problem between issuers and banks as hypothesized by Baron (1982), it also implies that contract design can mitigate the agency problem, at a cost.

Our results may help explain why in the U.S., seasoned issuers prefer to negotiate compensation after selecting their banks, even though competitive bidding is associated with lower fees (Bhagat and Frost (1986)). Minimizing fees may simply not be optimal. Our results suggest that part of the fee difference may represent payment for (better) performance.

We have also shown that banks specializing in corporate finance advice are associated with less underpriced IPOs compared to integrated securities houses or banks specializing in institutional brokerage. This suggests that the integration of corporate finance and broking under the same roof, common in the U.S. marketplace, can lead to agency conflicts that upset the delicate balancing of issuers' and investors' interests.

Finally, our results contribute to the debate of underwriter compensation in the U.S. The typical U.S. gross spread of seven percent is substantially greater than the average commission of two percent or the total spread of 4.35 percent in our U.K. sample. There are different interpretations. Perhaps seven percent is the optimal incentive in the U.S., given market conditions and issuer characteristics (Yeoman (2001)). Or perhaps U.S. banks are over-paid relative to the optimum: spreads may be so high that the marginal cost exceeds the marginal benefit of inducing greater selling effort. Chen and Ritter (2000) suggest that lack of competition among U.S. underwriters could be responsible for keeping spreads above competitive levels. In contrast, Hansen (2001) argues there is little evidence of collusion or lack of competition, and that underwriters compete on the (unobservable) quality of their services. Our results suggest such a quality-fee trade-off in the U.K. Whether U.S. issuers would be worse off if they reduced underwriter compensation remains an open question. 
But what may be more remarkable than the difference in the level of underwriter compensation is the apparent high degree of homogenization of not just spreads but underwriting contracts in general in the U.S. compared to the U.K. Behavior in the U.K. suggests that a one-size-fits-all contract finds little favor with issuers. 


\section{Endnotes}

${ }^{1}$ NASD Regulation, Inc. news release dated January 22, 2002.

${ }^{2}$ Penny stock offerings in the U.S. sometimes grant underwriters additional compensation in the form of warrants whose exercise price depends on the offer price. Dunbar (1995) shows that underpricing is reduced when warrants are used, consistent with the hypothesis that issuers choose compensation contracts that minimize the costs of going public.

${ }^{3}$ When the sponsor and broker are different banks, they split the fee and commission in some (often undisclosed) fashion.

${ }^{4}$ In addition to the flat fee, the sponsor and broker are reimbursed for reasonable "out-of-pocket expenses", which we ignore. Note that the flat fee does not include the annual retainers that the sponsor and broker are due to be paid after the IPO.

${ }^{5}$ A typical underwriting clause reads: "Under the Placing Agreement dated [on the impact day] the bank has agreed, conditionally on Admission taking place no later than [one week after impact day] or such later date (being no later than [two weeks after impact day]) as the Company and the bank may agree, as agent for the Company to place [number] new ordinary shares at the Placing Price and, to the extent that by $3 \mathrm{pm}$ on the business day prior to the day of Admission the bank has not procured placees for all of the remaining new ordinary shares, the bank will itself subscribe for the remaining new ordinary shares at the Placing Price."

${ }^{6}$ A typical disclosure reads: "In connection with the global offer, Bank XYZ may over-allocate or effect other transactions intended to enable it to satisfy any over-allocations or which stabilize, maintain, or otherwise affect the market price of the shares [...] at levels which might not otherwise prevail in the open market." 
${ }^{7}$ Note that such disclosure does not imply that after-market prices will, in fact, be stabilized. Actual stabilization has to be notified to Stock Exchange member firms when it is carried out.

${ }^{8}$ A typical disclosure reads: "This offer is not and does not constitute an offer to the public within the meaning of Schedule 11A to the Financial Services Act 1986. The offer is only open to persons whose ordinary activities involve them in acquiring, holding, managing or disposing of investments (as principal or agent) for the purposes of their businesses or otherwise in circumstances which will not result in an offer to the public in the United Kingdom within the meaning of the Public Offers of Securities Regulations 1995 (as amended) or the Financial Services Act 1986.”

${ }^{9}$ All market conditions variables in the paper are computed over the 180 -day period leading up to the pricing day. Our results are not materially affected using shorter windows up to 90 days or longer windows up to 365 days.

${ }^{10}$ Each service might also increase the flat fee, but given its lack of incentive properties the flat fee is not the focus of this study.

${ }^{11}$ This approach yields consistent though somewhat inefficient coefficients, since it ignores the possibility of correlation among the disturbances of the probit models (1) through (4) in Table 4. However, the alternative of fitting a quadri-variate probit model is computationally extremely hard due to the highly non-linear nature of the associated log-likelihood function.

${ }^{12}$ We do not control separately for the ten privatizations in the sample.

${ }^{13}$ In the case of multiple sponsors or brokers working on a deal, each is credited with the corresponding fraction of the deal.

${ }^{14} \mathrm{We}$ obtain qualitatively similar (albeit somewhat noisier) results if we measure independence using the sum of IPO proceeds rather than the number of IPOs. 
${ }^{15}$ Altinkilic and Hansen (2000) take issue with this view in the context of underwritten seasoned equity and bond issues, pointing out that the additional services required to sell larger issues in fact increase underwriter compensation at the margin. Since we control for the additional services directly, their criticism has less force in our model.

${ }^{16}$ James (1992) includes two additional variables: the probability that the firm will make a seasoned equity offer in the future, and the inverse offer price. We do not have data to estimate the former. The latter is not significant in our data.

${ }^{17}$ Altinkilic and Hansen's (2000) argument perhaps applies more properly to total spreads than to commissions. Applying their functional form, we find that total spreads in our dataset increase in inverse proceeds $(p<0.001)$ and decrease in proceeds over pre-money market capitalization $(p=0.042)$. Thus, unlike in Altinkilic and Hansen, we continue to find economies of scale even when the functional form allows for diseconomies.

${ }^{18}$ Let $P_{0}$ and $P_{1}$ denote the offer and first-day trading price, respectively, and let $P_{0}{ }^{*}$ denote the offer price an issuer would have achieved had it chosen a higher pay-for-performance incentive for its bankers. It is straightforward to show that the change in underpricing equals $\frac{P_{1}}{P_{0}} \frac{P_{0}^{*}-P_{0}}{P_{0}^{*}}$, that is, the product of the initial return (plus one) and the offer price improvement. (This ignores the effect that paying higher commissions has on $P_{1}$, as well as dilution effects (see Barry (1989)).) So, for a company with high (low) underpricing, an eleven percentage point reduction in the initial return implies a relatively small (large) price improvement.

${ }^{19}$ In the $\log$ specification, the change in underpricing equals $-\ln \left(P_{0}^{*} / P_{0}\right)$ using the notation of footnote 18 . 


\section{References}

Altinkilic, O., Hansen, R.S., 2000. Are there economies of scale in underwriting fees? Evidence of rising external financing costs. Review of Financial Studies 13, 191-218.

Baron, D.P., 1982. A model of the demand for investment banking advising and distribution services for new issues. Journal of Finance 37, 955-976.

Barry, C.B., 1989. Initial public offering underpricing: The issuer's view - a comment. Journal of Finance 44, 1099-1103.

Benveniste, L.M., Spindt, P.A., 1989. How investment bankers determine the offer price and allocation of new issues. Journal of Financial Economics 24, 343-61.

Bhagat, S., Frost, P., 1986. Issuing costs to existing shareholders in competitive and negotiated underwritten public utility equity offers. Journal of Financial Economics 3, 113-127.

Biais, B., Bossaerts, P. Rochet, J.-C., 2002. An optimal IPO mechanism. Review of Economic Studies 69, 117-146.

Busaba, W., Benveniste, L.M., Guo, R.-J., 2001. The withdrawal of initial public offerings during the premarket. Journal of Financial Economics 60, 73-102.

Carter, R.B., Manaster, S., 1990. Initial public offerings and underwriter reputation. Journal of Finance 45, 1045-1067.

Chen, H.-C., Ritter, J.R., 2000. The seven percent solution. Journal of Finance 55, 1105-1131.

Davidson, R., MacKinnon, J.G., 1993. Estimation and Inference in Econometrics. Oxford University Press.

Demsetz, H., Lehn, K., 1985. The structure of corporate ownership: causes and consequences. Journal of Political Economy 93, 1155-1177.

Dunbar, C.G., 1995. The use of warrants as underwriter compensation in initial public offerings. Journal of Financial Economics 38, 59-78.

Dunbar, C.G., 2000. Factors affecting investment bank initial public offering market share. Journal of Financial Economics 55, 3-41.

Fama, E.F., French, K.R., 1997. Industry costs of equity. Journal of Financial Economics 43, 153-194.

Habib, M.A., Ljungqvist, A.P., 2001. Underpricing and entrepreneurial wealth losses: theory and evidence. Review of Financial Studies 14, 433-458.

Hanley, K., 1993. The underpricing of initial public offerings and the partial adjustment phenomenon. Journal of Financial Economics 34, 231-50. 
Hansen, R.S., 2001. Do investment banks compete in IPOs? The advent of the ' $7 \%$ plus contract'. Journal of Financial Economics 59, 313-346.

Heckman, J., 1979. Sample selection bias as a specification Error. Econometrica 47, 153-161.

James, C., 1992, Relationship-specific assets and the pricing of underwriter services. Journal of Finance 47, 1865-1885.

James, C., Wier, P., 1990. Borrowing relationships, intermediation and the cost of issuing public securities. Journal of Financial Economics 28, 149-171.

Ljungqvist, A.P., Jenkinson, T.J., Wilhelm, W.J., 2003. Global integration in primary equity markets: the role of U.S. banks and U.S. investors. Review of Financial Studies 16, forthcoming (Spring).

Ljungqvist, A.P., Wilhelm, W.J., 2002. IPO allocations: discriminatory or discretionary? Journal of Financial Economics 65, 167-201.

Ljungqvist, A.P., Wilhelm, W.J., 2003. IPO pricing in the dot-com bubble. Journal of Finance 58, forthcoming (April).

Loughran, T., Ritter, J.R., 2002a. Why don't issuers get upset about leaving money on the table in IPOs? Review of Financial Studies 15, 413-443.

Loughran, T., Ritter, J.R., 2002b. Why has IPO underpricing changed over time? Unpublished working paper, University of Florida.

Lowry, M., Schwert, G.W., 2002. IPO market cycles: bubbles or sequential learning? Journal of Finance 57, 1171-1200.

Ritter, J., 1987. The costs of going public. Journal of Financial Economics 19, 269-281.

Ritter, J., Welch, I., 2002. A review of IPO activity, pricing, and allocations. Journal of Finance 57, 1795-1828.

Rock, K. 1986. Why new issues are underpriced. Journal of Financial Economics 15, 187-212.

Sherman, A., 2000. IPOs and long-term relationships: an advantage of book building. Review of Financial Studies 13, 697-714.

Welch, I., 1991. An empirical examination of models of contract choice in initial public offerings. Journal of Financial and Quantitative Analysis 26, 497-518.

Yeoman, J.C., 2001. The optimal spread and offering price for underwritten securities. Journal of Financial Economics 62, 169-198. 
Table 1.

\section{Descriptive sample statistics.}

The sample consists of the 1,008 (out of 1,058) IPOs on the London Stock Exchange for which IPO contracts are available. Gross proceeds equal the offer price times the number of shares sold, including shares sold under an over-allotment option where exercised. Foreign currencies are converted into pound sterling $(£)$ using exchange rates on the pricing day. All currency amounts are expressed in December 2001 purchasing power terms, using the Retail Price Index (excluding mortgage interest) deflator. $£ 1$ was worth roughly $\$ 2$ prior to summer 1992 and $\$ 1.50$ thereafter. Listings on the junior market are on the Unlisted Securities Market (USM) from 1991 to 1995, or on the Alternative Investment Market (AIM) from June 1995. Age at IPO is the IPO year minus the year operations commenced, as identified in the prospectus. Internet-related companies are identified based on a reading of the business description section of each prospectus. Indebtedness includes secured and unsecured loans, bank overdrafts, leasing commitments, and loan guarantees. It is prominently disclosed in U.K. prospectuses, and reflects indebtedness at the time of the IPO rather than at the date of the last audited accounts. Sales are consolidated revenues in the most recent twelve-month accounting period before the IPO, as reported in the prospectus. The initial return is defined as the first-day closing price divided by the offer price, minus one. First-day closing prices are from Datastream, with all initial returns in excess of 30 percent cross-checked using Reuters. We lack after-market prices for 10 IPOs.

\begin{tabular}{|c|c|c|c|c|c|c|c|c|c|c|c|c|c|c|}
\hline & \multicolumn{2}{|c|}{ Number of IPOs } & \multicolumn{2}{|c|}{$\begin{array}{c}\text { Gross proceeds } \\
(£ \mathrm{~m}, \text { real })\end{array}$} & \multirow[b]{2}{*}{$\begin{array}{r}\% \text { listed } \\
\text { on } \\
\text { junior } \\
\text { market }\end{array}$} & \multicolumn{2}{|c|}{ Age at IPO } & \multirow[b]{2}{*}{$\begin{array}{r}\% \\
\text { internet- } \\
\text { related }\end{array}$} & \multicolumn{2}{|c|}{$\begin{array}{l}\text { Indebtedness } \\
(£ \mathrm{~m}, \text { real })\end{array}$} & \multicolumn{2}{|c|}{ Sales (£m, real) } & \multicolumn{2}{|c|}{$\begin{array}{l}\text { Initial return } \\
(\%)\end{array}$} \\
\hline & total & $\begin{array}{r}\mathrm{w} / \\
\text { under- } \\
\text { writing } \\
\text { contract }\end{array}$ & mean & edian & & mean & median & & mean & median & mean & median & mean & st.dev. \\
\hline all years & 1,058 & 1,008 & 53.3 & 9.5 & 49.7 & 20.3 & 8 & 14.0 & 38.5 & 1.8 & 74.4 & 6.8 & 29.3 & 121.1 \\
\hline 1991 & 16 & 6 & 27.2 & 18.4 & 33.3 & 97.2 & 92 & 0.0 & 57.1 & 19.3 & 58.3 & 36.9 & 12.9 & 22.3 \\
\hline 1992 & 26 & 17 & 115.1 & 38.1 & 17.6 & 30.9 & 15 & 0.0 & 90.0 & 7.3 & 154.4 & 66.1 & 7.1 & 14.0 \\
\hline 1993 & 78 & 75 & 61.4 & 24.6 & 6.7 & 27.1 & 14 & 0.0 & 58.6 & 4.6 & 129.8 & 28.1 & 13.6 & 22.4 \\
\hline 1994 & 121 & 117 & 54.9 & 19.4 & 7.7 & 33.6 & 12 & 0.9 & 56.7 & 6.7 & 68.0 & 25.1 & 7.3 & 10.5 \\
\hline 1995 & 64 & 64 & 38.3 & 10.4 & 23.4 & 24.6 & 8 & 0.0 & 20.3 & 4.2 & 49.6 & 20.0 & 16.1 & 17.5 \\
\hline 1996 & 166 & 163 & 56.4 & 7.3 & 56.4 & 21.6 & 9 & 3.1 & 44.7 & 1.8 & 106.0 & 7.1 & 13.4 & 16.0 \\
\hline 1997 & 128 & 124 & 43.2 & 7.2 & 53.2 & 27.1 & 11 & 1.6 & 32.4 & 1.2 & 85.9 & 7.6 & 11.9 & 12.5 \\
\hline 1999 & 77 & 71 & 87.9 & 4.7 & 64.8 & 14.2 & 5 & 31.0 & 60.8 & 1.0 & 86.5 & 4.7 & 80.8 & 162.3 \\
\hline 2000 & 228 & 221 & 40.7 & 8.9 & 71.5 & 5.5 & 3 & 44.8 & 13.5 & 0.7 & 15.7 & 0.4 & 65.4 & 233.0 \\
\hline 2001 & 80 & 77 & 55.3 & 3.0 & 89.6 & 14.5 & 5 & 13.0 & 58.7 & 1.1 & 78.0 & 1.7 & 14.9 & 27.3 \\
\hline
\end{tabular}


Table 2.

\section{U.K. IPO compensation.}

Bank compensation in U.K. IPOs usually consists of a flat fee and a commission paid on each share sold. Commissions are calculated as a percent of the offer price. Both the flat fee and the commission rate are agreed before the offer is priced. The flat fee is expressed in December 2001 purchasing power terms. The total spread equals the bank's total compensation from the flat fee and commissions, divided by the gross proceeds of the offer. We know the commission rate for 958 of the 1,008 contracts. The size of the flat fee element is disclosed in 795 contracts. $£ 1$ was worth roughly $\$ 2$ prior to summer 1992 and $\$ 1.50$ thereafter.

\begin{tabular}{|c|c|c|c|c|c|c|c|c|c|c|c|c|}
\hline & \multicolumn{3}{|c|}{ Commission $(\%)$} & \multicolumn{3}{|c|}{ Flat fee $\left(£^{‘} 000\right.$ s, real $)$} & \multicolumn{3}{|c|}{$\begin{array}{l}\text { Total spread (flat fee/proceeds }+ \\
\text { commission) }(\%)\end{array}$} & \multicolumn{3}{|c|}{$\begin{array}{l}\text { Flat fee as percent of total bank } \\
\text { compensation }\end{array}$} \\
\hline & mean & st.dev. & median & mean & st.dev. & median & mean & st.dev. & median & mean & st.dev. & median \\
\hline all years & 2.01 & 1.45 & 1.75 & 139.1 & 195.8 & 88.4 & 4.35 & 3.34 & 3.78 & 43.4 & 31.9 & 43.0 \\
\hline 1991 & 1.41 & 0.88 & 1.37 & 143.7 & 237.0 & 69.6 & 3.43 & 1.98 & 2.97 & 45.8 & 38.8 & 52.4 \\
\hline 1992 & 1.73 & 1.44 & 1.31 & 219.4 & 256.6 & 185.1 & 3.47 & 1.81 & 3.73 & 31.1 & 28.0 & 30.8 \\
\hline 1993 & 1.34 & 0.96 & 1.19 & 174.1 & 161.5 & 144.7 & 2.54 & 1.74 & 2.12 & 37.4 & 28.5 & 39.2 \\
\hline 1994 & 1.18 & 0.88 & 0.83 & 183.0 & 178.1 & 151.4 & 2.65 & 1.64 & 2.28 & 45.6 & 29.9 & 50.6 \\
\hline 1995 & 1.49 & 1.25 & 1.00 & 151.1 & 213.3 & 116.0 & 3.73 & 2.16 & 3.78 & 49.2 & 32.9 & 47.8 \\
\hline 1996 & 1.78 & 1.32 & 1.50 & 138.7 & 219.9 & 72.4 & 3.89 & 2.67 & 3.64 & 44.8 & 31.7 & 44.2 \\
\hline 1997 & 1.82 & 1.24 & 1.75 & 117.4 & 183.3 & 55.7 & 3.89 & 2.34 & 3.56 & 44.0 & 33.0 & 44.3 \\
\hline 1998 & 2.03 & 1.41 & 1.89 & 144.6 & 189.9 & 86.8 & 4.43 & 2.32 & 4.00 & 45.4 & 31.3 & 45.3 \\
\hline 1999 & 2.45 & 1.36 & 2.58 & 63.8 & 88.5 & 31.4 & 4.95 & 4.02 & 4.00 & 38.9 & 33.3 & 33.9 \\
\hline 2000 & 2.77 & 1.63 & 3.00 & 145.6 & 227.8 & 82.9 & 4.87 & 2.38 & 4.40 & 39.9 & 32.6 & 32.7 \\
\hline 2001 & 2.71 & 1.50 & 3.00 & 118.7 & 137.1 & 100.6 & 7.70 & 6.79 & 5.73 & 52.2 & 30.6 & 51.5 \\
\hline
\end{tabular}


Table 3.

\section{IPO services in the U.K.}

We focus on five services that U.K. issuers can purchase from their investment bankers: underwriting, after-market price stabilization, marketing of the IPO to U.S. investors, retail participation, and analyst coverage. The first four columns show the fraction of IPOs in the sample that include the first four of these services. To measure the quality of analyst coverage, we use the IPO broker's percent of weighted votes cast in the annual Extel Survey of Investment Analysts. This ranges from 0.18 percent (Credit Agricole Indosuez Cheuvreux in 2000) to 18.14 percent (Merrill Lynch in 1998). See text for further details. Unranked brokers are those not ranked in the Extel survey.

\begin{tabular}{|c|c|c|c|c|c|c|c|}
\hline & \multicolumn{4}{|c|}{ Fraction ... } & \multicolumn{3}{|c|}{ Analyst ranking } \\
\hline & $\begin{array}{l}\text { under- } \\
\text { written }\end{array}$ & $\begin{array}{c}\text { flagging } \\
\text { possibility } \\
\text { of price } \\
\text { support }\end{array}$ & $\begin{array}{l}\text { marketed in } \\
\text { the U.S. }\end{array}$ & $\begin{array}{c}\mathrm{w} / \text { retail } \\
\text { partici- } \\
\text { pation }\end{array}$ & $\begin{array}{l}\text { Mean (\% of } \\
\text { weighted } \\
\text { votes in } \\
\text { Extel } \\
\text { Surveys) } \\
\end{array}$ & $\begin{array}{c}\text { Fraction w/ } \\
\text { unranked } \\
\text { broker }\end{array}$ & $\begin{array}{l}\text { Proceeds- } \\
\text { weighted } \\
\text { fraction w/ } \\
\text { unranked } \\
\text { broker }\end{array}$ \\
\hline all years & 67.0 & 8.5 & 10.3 & 24.1 & 2.25 & 62.7 & 11.1 \\
\hline 1991 & 50.0 & 0.0 & 0.0 & 50.0 & 1.77 & 83.3 & 80.2 \\
\hline 1992 & 88.2 & 11.8 & 11.8 & 58.8 & 5.96 & 47.1 & 39.2 \\
\hline 1993 & 93.3 & 2.7 & 5.3 & 56.0 & 5.30 & 33.3 & 6.9 \\
\hline 1994 & 93.2 & 3.4 & 8.5 & 35.0 & 3.69 & 47.0 & 13.7 \\
\hline 1995 & 71.9 & 4.7 & 9.4 & 28.1 & 2.87 & 59.4 & 10.6 \\
\hline 1996 & 65.0 & 4.9 & 6.7 & 15.3 & 1.95 & 63.2 & 7.3 \\
\hline 1997 & 58.9 & 6.5 & 4.8 & 12.1 & 1.83 & 66.9 & 10.0 \\
\hline 1998 & 67.1 & 9.6 & 13.7 & 15.1 & 2.37 & 61.6 & 7.5 \\
\hline 1999 & 54.9 & 18.3 & 21.1 & 21.1 & 1.43 & 70.4 & 4.4 \\
\hline 2000 & 58.4 & 14.6 & 15.8 & 21.5 & 1.27 & 69.2 & 17.7 \\
\hline 2001 & 46.8 & 7.8 & 6.5 & 19.5 & 0.61 & 87.0 & 7.6 \\
\hline
\end{tabular}


Table 4.

\section{Demand regressions.}

In columns (1) through (4), we report probit regressions of issuers' demands for the first four investment banking services presented in Table 3. In column (5), we report an OLS regression of issuers' choice of analyst quality. Market returns are estimated using the FT-SE All Share index excluding investment trusts. The mean initial return in the 180 days before pricing is computed over all IPOs completed during that period. The IPO withdrawal rate is the number of withdrawn IPOs over the sum of withdrawn and completed IPOs in the previous 365 days. Data on the pre-IPO CEO equity stake are hand-collected from prospectuses. All other variables are as defined in Tables 1 and 3. The model of the demand for retail participation in (4) includes year dummies for 1991 through 1995 to proxy for the regulatory changes concerning mandatory participation of retail investors. To aid the economic interpretation of the results in (1) through (4), the table shows the change in the probability for an infinitesimal change in each independent, continuous variable and, by default, the discrete change in the probability for dummy variables, rather than the probit coefficients. White heteroskedasticity-consistent standard errors are shown in italics. We use ${ }^{* * * * * *}$, and ${ }^{*}$ to denote significance at the one percent, five percent, and 10 percent level (two-sided), respectively. 
Table 4.

(Continued)

\begin{tabular}{|c|c|c|c|c|c|}
\hline & \multicolumn{4}{|c|}{ Dependent variable: Dummy $=1$ if $\ldots$} & \multirow[b]{2}{*}{$\begin{array}{c}\text { analyst } \\
\text { ranking } \\
(5) \\
\end{array}$} \\
\hline & $\begin{array}{c}\text { under- } \\
\text { written } \\
(1) \\
\end{array}$ & $\begin{array}{l}\text { flagging } \\
\text { possibility } \\
\text { of price } \\
\text { support } \\
(2)\end{array}$ & $\begin{array}{l}\text { marketed } \\
\text { in the U.S. } \\
\text { (3) }\end{array}$ & $\begin{array}{c}\text { retail } \\
\text { partici- } \\
\text { pation } \\
(4)\end{array}$ & \\
\hline \multicolumn{6}{|l|}{ Market conditions } \\
\hline \multirow[t]{2}{*}{ Market return, 180 days before pricing } & -0.187 & 0.020 & -0.016 & -0.315 & 1.789 \\
\hline & 0.221 & 0.019 & 0.042 & 0.220 & 1.736 \\
\hline \multirow[t]{2}{*}{ St.dev. of daily market return, 180 days before pricing } & 0.518 & $2.496^{* * *}$ & $3.192^{* *}$ & 12.781 & -91.479 \\
\hline & 8.848 & 1.300 & 1.684 & 10.388 & 65.648 \\
\hline \multirow[t]{2}{*}{ Mean initial return, 180 days before pricing } & -0.046 & -0.005 & -0.005 & -0.042 & -0.475 \\
\hline & 0.045 & 0.004 & 0.007 & 0.047 & 0.306 \\
\hline \multirow[t]{2}{*}{ Number of IPOs, 180 days before pricing } & -0.001 & $0.0001^{* * *}$ & 0.000 & 0.001 & $-0.008^{*}$ \\
\hline & 0.001 & 0.00007 & 0.000 & 0.001 & 0.004 \\
\hline \multirow[t]{2}{*}{ IPO withdrawal rate, year to pricing } & $-0.551^{* *}$ & 0.006 & 0.046 & -0.150 & -0.552 \\
\hline & 0.276 & 0.020 & 0.041 & 0.349 & 2.336 \\
\hline \multicolumn{6}{|l|}{ Firm and offer characteristics } \\
\hline \multirow[t]{2}{*}{$\ln ($ gross proceeds in $£ \mathrm{~m})$} & $0.162^{* * *}$ & $0.015^{* * *}$ & $0.036^{* * *}$ & $0.111^{* * *}$ & $1.211^{* * * *}$ \\
\hline & 0.017 & 0.007 & 0.009 & 0.015 & 0.126 \\
\hline \multirow[t]{2}{*}{$\ln (1+$ age $)$} & $0.026^{*}$ & 0.000 & $-0.005^{* *}$ & 0.021 & -0.097 \\
\hline & 0.016 & 0.001 & 0.003 & 0.014 & 0.116 \\
\hline \multirow[t]{2}{*}{$\ln (1+$ sales in $£ \mathrm{~m})$} & 0.027 & $-0.004^{* * * *}$ & -0.004 & -0.004 & $0.295^{* *}$ \\
\hline & 0.017 & 0.002 & 0.003 & 0.014 & 0.140 \\
\hline \multirow[t]{2}{*}{$\ln (1+\mathrm{debt}$ in $£ \mathrm{~m})$} & 0.010 & $0.002^{*}$ & 0.002 & $0.027^{* *}$ & $0.282^{* *}$ \\
\hline & 0.018 & 0.001 & 0.002 & 0.012 & 0.141 \\
\hline \multirow[t]{2}{*}{ Dummy $=1$ if internet-related } & $-0.119^{* *}$ & -0.002 & 0.012 & 0.059 & $0.537^{*}$ \\
\hline & 0.057 & 0.003 & 0.014 & 0.055 & 0.292 \\
\hline \multirow[t]{2}{*}{ CEO equity stake pre-IPO (in \%) } & -0.001 & 0.000 & $0.0002^{*}$ & -0.001 & $-0.009^{* *}$ \\
\hline & 0.001 & 0.000 & 0.0001 & 0.001 & 0.004 \\
\hline \multirow[t]{2}{*}{ Dummy $=1$ if CEO sells stock in the IPO } & $0.079^{* *}$ & -0.0005 & -0.003 & $-0.132^{* * *}$ & -0.184 \\
\hline & 0.035 & 0.003 & 0.006 & 0.027 & 0.269 \\
\hline \multirow[t]{2}{*}{ Constant } & & & & & -0.083 \\
\hline & & & & & 0.771 \\
\hline Pseudo $R^{2} /$ adjusted $R^{2}$ & $27.4 \%$ & $59.2 \%$ & $54.6 \%$ & $30.1 \%$ & $37.1 \%$ \\
\hline Wald test: all coeff. jointly zero $\left(\chi^{2} / F\right)$ & $263.6^{* * *}$ & $136.4^{* * *}$ & $182.6^{* * *}$ & $225.4^{* * * *}$ & $34.5^{* * *}$ \\
\hline
\end{tabular}


Table 5.

Bank compensation regression.

We estimate the determinants of the commission rate (in percent) using Heckman's (1979) two-step treatment effects model. In the first step, we generate inverse Mills' ratios from the four probit models in Table 4. In the second step, we include these alongside binary variables for underwriting, price support, U.S. marketing, and retail participation in a least-squares regression with commission rates as the dependent variable. Sponsor independence is measured as the ratio of the number of deals a bank has sponsored over the sample period to the sum of the number of deals it has sponsored and the number of deals it has brokered. This ratio varies between zero and one, with one corresponding to a sponsor that never brokers IPO deals. All other variables are defined as in Table 4. White heteroskedasticity-consistent standard errors are shown in italics. We use ${ }^{* * * *},{ }^{* *}$, and ${ }^{*}$ to denote significance at the one percent, five percent, and 10 percent level (two-sided), respectively. The number of observations is 950 .

Dependent variable: Commissions

(6)

IPO services

Dummy $=1$ if underwritten

$1.115^{* *}$

0.489

Dummy=1 if flagging possibility of price support

$1.755^{* * *}$

0.667

Dummy=1 if marketed in the U.S.

$2.060^{* * * *}$

0.731

Dummy $=1$ if retail participation

0.059

0.319

Inverse Mills' ratios

Underwriting

$-0.719^{* *}$

0.289

Price support

0.097

0.357

U.S. marketing

$-0.751^{* *}$

0.372

Retail participation

0.139

0.209

IPO advisers

Analyst ranking

$-0.003$

0.008

Sponsor independence

$0.473^{* *}$

0.186

Sponsor independence $\times($ sponsor $=$ broker $)$

$-0.118$

0.200 
Table 5.

(Continued)

(6)

\section{Market conditions}

Market return, 180 days before pricing (in \%) $\quad-0.009$

0.006

St.dev. of daily market return, 180 days before pricing (in \%) $\quad 0.462^{* *}$

0.216

Mean initial return, 180 days before pricing (in \%)

$0.003^{* *}$

0.001

Number of IPOs, 180 days before pricing

$0.003^{*}$

0.002

IPO withdrawal rate, year to pricing (in \%)

$0.014^{* * *}$

0.005

Firm and offer characteristics

$\ln$ (gross proceeds in $£ \mathrm{~m}$ )

$-0.243^{* *}$

0.114

$\ln (1+$ age $)$

$0.079^{* *}$

0.039

$\ln (1+$ sales in $£ \mathrm{~m})$

$-0.238^{* * *}$

0.042

$\ln (1+$ debt in $£ \mathrm{~m})$

$-0.035$

0.034

Dummy $=1$ if internet-related

0.100

0.165

Monitoring incentives

CEO equity stake pre-IPO (in \%)

0.001

0.002

Dummy $=1$ if CEO sells stock in the IPO

$-0.223^{* *}$

0.098

Constant

$0.822^{* * *}$

0.359

Adjusted $R^{2}$

$37.6 \%$

$F$-test: all coeff. jointly zero

$34.30^{* * *}$ 


\section{Table 6. \\ Initial return regressions.}

We estimate the effect of "excess commissions" on initial returns (in percent) using least squares. Excess commissions are computed as the residuals from the commission regression shown in Table 5. Excess commissions will be positive (negative) when issuers pay more (less) than their bundle of services, market conditions, and characteristics require on average. Thus, higher effort incentives correspond to paying a commission rate in excess of that predicted by model (6) in Table 5. We expect excess commissions to have a negative effect on initial returns. In model (9), we include a variable that equals the price revision (offer price / midpoint - 1) when data on the (midpoint of the) initial price range are available, and zero otherwise. Models (8) and (9) allow for analyst ranking being endogenous using log proceeds and a dummy equaling one for VC-backed companies as instruments. Model (10) re-estimates (9) but with log initial returns as the dependent variable. The Sargan statistic is a test of the validity of our instruments, allowing for arbitrary heteroskedasticity. White heteroskedasticity-consistent standard errors are shown in italics. We use ${ }^{* * *},{ }^{* *}$, and ${ }^{*}$ to denote significance at the one percent, five percent, and 10 percent level (two-sided), respectively.

\begin{tabular}{|c|c|c|c|c|}
\hline \multirow[t]{2}{*}{ Dependent variable: } & \multicolumn{3}{|c|}{ Initial return (in \%) } & \multirow{2}{*}{$\begin{array}{c}\text { Log initial } \\
\text { return } \\
(10) \\
\end{array}$} \\
\hline & (7) & (8) & (9) & \\
\hline \multicolumn{5}{|l|}{ Firm characteristics } \\
\hline \multirow[t]{2}{*}{$\ln (1+$ age $)$} & $-8.472^{* * *}$ & $-8.048^{* * *}$ & $-7.931^{* * *}$ & $-0.027^{* * *}$ \\
\hline & 2.160 & 2.197 & 2.194 & 0.008 \\
\hline \multirow[t]{2}{*}{$\ln (1+\mathrm{debt}$ in $£ \mathrm{~m})$} & $-3.162^{* * *}$ & 3.902 & 4.125 & -0.002 \\
\hline & 1.017 & 3.012 & 3.027 & 0.009 \\
\hline \multirow[t]{2}{*}{ Dummy $=1$ if internet-related } & $59.308^{* * *}$ & $64.531^{* * *}$ & $64.805^{* * *}$ & $0.162^{* * *}$ \\
\hline & 22.833 & 24.242 & 24.251 & 0.054 \\
\hline \multicolumn{5}{|l|}{ Monitoring incentives } \\
\hline \multirow[t]{2}{*}{ CEO equity stake pre-IPO (in \%) } & -0.165 & $-0.298^{* *}$ & $-0.288^{* *}$ & $-0.001^{* *}$ \\
\hline & 0.120 & 0.146 & 0.146 & 0.0004 \\
\hline \multirow[t]{2}{*}{ Dummy $=1$ if CEO sells stock in the IPO } & $-12.490^{* *}$ & $-7.951^{*}$ & $-8.553^{*}$ & -0.021 \\
\hline & 5.013 & 4.426 & 4.460 & 0.015 \\
\hline \multicolumn{5}{|l|}{ Market conditions } \\
\hline \multirow[t]{2}{*}{ Market return, 180 days before pricing (in \%) } & -0.034 & 0.214 & 0.184 & 0.002 \\
\hline & 0.258 & 0.270 & 0.272 & 0.001 \\
\hline \multirow[t]{2}{*}{ St.dev. of daily market return 180 days before pricing (in \%) } & 7.099 & -5.081 & -3.832 & 0.008 \\
\hline & 12.269 & 13.055 & 13.108 & 0.049 \\
\hline \multirow[t]{2}{*}{ Mean initial return, 180 days before pricing (in \%) } & $0.237^{* *}$ & $0.204^{*}$ & $0.200^{*}$ & $0.0008^{* *}$ \\
\hline & 0.120 & 0.120 & 0.120 & 0.0004 \\
\hline \multirow[t]{2}{*}{ Number of IPOs, 180 days before pricing } & $-0.621^{* * *}$ & $-0.719^{* * *}$ & $-0.716^{* * *}$ & $-0.0020^{* * *}$ \\
\hline & 0.219 & 0.250 & 0.249 & 0.0005 \\
\hline \multirow[t]{2}{*}{ IPO withdrawal rate, year to pricing (in \%) } & $-1.181^{*}$ & $-1.378^{* *}$ & $-1.393^{* *}$ & $-0.0030^{* *}$ \\
\hline & 0.619 & 0.689 & 0.691 & 0.0015 \\
\hline
\end{tabular}




\section{Table 6.}

\section{(Continued)}

\begin{tabular}{|c|c|c|c|c|}
\hline \multirow[t]{2}{*}{ Dependent variable: } & \multicolumn{3}{|c|}{ Initial return (in \%) } & \multirow{2}{*}{$\begin{array}{c}\text { Log initial } \\
\text { return }\end{array}$} \\
\hline & $(7)$ & (8) & $(9)$ & \\
\hline \multicolumn{5}{|l|}{ IPO advisers } \\
\hline \multirow[t]{2}{*}{ Analyst ranking } & $-0.930^{* *}$ & $-7.286^{* * *}$ & $-7.357^{* * *}$ & $-0.020^{* * *}$ \\
\hline & 0.405 & 2.765 & 2.766 & 0.007 \\
\hline \multirow[t]{2}{*}{ Sponsor independence } & $-28.842^{* *}$ & $-33.669^{* *}$ & $-33.621^{* *}$ & $-0.121^{* *}$ \\
\hline & 13.530 & 15.027 & 15.042 & 0.048 \\
\hline \multirow[t]{2}{*}{ Sponsor independence $\times($ sponsor $=$ broker $)$} & $-25.356^{* *}$ & $-28.410^{* *}$ & $-28.211^{* *}$ & $-0.150^{* * *}$ \\
\hline & 11.637 & 12.206 & 12.253 & 0.052 \\
\hline \multicolumn{5}{|l|}{ Pay-for-performance incentives } \\
\hline \multirow[t]{2}{*}{ Predicted commission rate (in \%) } & -5.071 & -0.489 & -0.834 & 0.004 \\
\hline & 3.126 & 2.828 & 2.836 & 0.011 \\
\hline \multirow[t]{2}{*}{ Excess commission rate (in \%) } & $-11.096^{* *}$ & $-11.128^{* *}$ & $-11.296^{* *}$ & $-0.029^{* * *}$ \\
\hline & 5.328 & 5.306 & 5.319 & 0.011 \\
\hline \multicolumn{5}{|l|}{ Partial adjustment } \\
\hline \multirow[t]{2}{*}{ Price revision (in \%) } & & & $0.386^{*}$ & $0.003^{* * *}$ \\
\hline & & & 0.207 & 0.001 \\
\hline \multirow[t]{2}{*}{ Constant } & $135.194^{* * *}$ & $153.363^{* * *}$ & $152.887^{* * *}$ & $0.524^{* * *}$ \\
\hline & 38.280 & 44.027 & 43.966 & 0.090 \\
\hline Adjusted $R^{2}$ & $10.9 \%$ & $13.5 \%$ & $13.4 \%$ & $34.1 \%$ \\
\hline$F$-test: all coeff. jointly zero & $3.5^{* * *}$ & $2.8^{* * *}$ & $2.8^{* * *}$ & $6.38^{* * *}$ \\
\hline Sargan $\chi^{2}$ statistic (overidentification test of all instruments) & & 0.627 & 0.569 & 0.617 \\
\hline
\end{tabular}

